\title{
Institution of The Judicial Commission of The Republic of Indonesia As an Ethical Court for Judges
}

\author{
Jaja Ahmad Jayus, Lecturer at the Faculty of Law, Pasundan University, Bandung, Indonesia, \\ jayus_ahmad@yahoo.co.id,ORCID.0000-0009-2000-0765 \\ Taufiqurrohman Syahuri, Lecturer at the Faculty of Law of "Veteran" National Development University of \\ Jakarta Indonesia, tsyahuri@gmail.com, ORCID: 0000-0008-0010-2056-0765 \\ Wahyu Nugroho, Lecturer at the Faculty of Law, Sahid University Jakarta Indonesia, \\ wahyulaw86@yahoo.com,ORCID: ORCID.0000-0003-1945-0434
}

\begin{abstract}
The Judicial Commission of the Republic of Indonesia has the authority in addition to recruiting prospective Supreme Court justices, also given the authority to maintain and uphold the honor, dignity and behavior of judges, it must be interpreted that the honor, dignity and behavior of judges must be safeguarded so as not to fall down either due to his own actions or due to actions by other party. The legal basis of the Judicial Commission is stated in the constitution of Article 24B of the 1945 Constitution, the Judicial Commission Law (Law KY) No. 18 of 2011 as Amendments to Law Number 22 of 2004, and Law Number 3 of 2009 concerning Second Amendment to Law Number 14 of 1985 concerning the Supreme Court (Law MA). The judge's decision is the judge's dignity and honor, so if the judge plays his decision, in fact he has dropped his own dignity and honor. Likewise, if a judge's behavior is inappropriate or not in accordance with moral code, both inside and outside his official duties, in fact he has dropped his own honor and dignity as a judge, so this is where the Judicial Commission has the authority to enforce it, from the mild sanction, moderate to severe categories. This article discusses the institutional relationship with the Judicial Commission of the Republic of Indonesia as an ethical court for judges, considering the independence of judges in law enforcement practices in violation of ethical codes in various forms, thus the Judicial Commission as a supervisory and balancing function of the judiciary (judicial power).
\end{abstract}

Keywords: judicial commission, judge, ethics, court, sanctions. Received: 04.12.2020 Accepted: 15.01.2021

Published: 04.02.2021

\section{INTRODUCTION}

Judges are the main law enforcement actors in the court who have more roles when compared to prosecutors, lawyers and clerks. At the time it was enforced, the law began to enter the das sein (the real) territory and left the das sollen (which should be) territory. The law is no longer just a row of dead articles contained in a statutory regulation, but has been "turned on" by the living interpreter named judge (A. Ahsin Tohari, 2004). In deciding a case, the judge must combine three important things, namely legal certainty, legal usefulness, and legal justice. In that way, the legal considerations which form the basis of the decision will be better.

More than that, the judge also needs to have the ability to control thoughts that can provide direction in thinking and acting in carrying out his judicial activities, namely moral philosophy. It is this factor of moral philosophy that is important to ensure that the freedom of judges as law enforcers is balanced with idealism to provide justice for justice seekers. In another sense, judicial independence must also be balanced with judicial accountability (Blueprint for Judicial Commission Update, 2010).

As we all know, the position of judge on the one hand is a very noble position, and on the other hand, if not careful, can lower his dignity because many temptations are ready to plunge him. Judge's position can be said to be a position very close to worldly temptations. Imagine, in the hands of a judge the fate and future of someone will be determined. People who were rich and famous as donors in their environment, for example, suddenly fell as human dignity because they went to prison due to the judge's decision. Therefore, it has become a common view that those who deal with the court will try their best, by all means (read justifying all means) doing everything as long as the judge's decision can side with him.

A good judge will decide a case according to the truth of his knowledge, on the contrary a bad judge will decide a case not using his knowledge, he will consciously betray the knowledge he actually knows. Therein lies the importance of the independence of judges to be accompanied and maintained with the accountability of judges. The independence of judges without the accountability of judges will potentially lead to arbitrary decisions. So the independence of judges is very risky to give birth to 
independence if without accountability and control that is contrary to the idea of limiting power. These conditions can give rise to a judicial tyrannical situation that marginalizes ideals to uphold law and justice. The principle of judicial independence has attracted much attention and been critically analysed from a number of different perspectives and, not unexpectedly, accorded different meanings. Judicial accountability, which is often considered to complement judicial independence, is a fluid and evolving concept, the precise parameters of which are undetermined (John Lowndes, 2016).

Judges' independence is not in a vacuum and their independence is not absolute. Judges are not perfect human beings and are very likely to make mistakes, therefore the independence of judges must be accompanied by responsibility. Even Plato in the past has warned of imperfections of law as the emergence of law enforcement practices that are even in line with the law, but are contrary to human rights and a sense of justice. Often found a number of judges' decisions that do not have the power of morality in them. Therefore, in this article it discusses institutional Judicial Commission of the Republic of Indonesia as an ethical court for judges, given the independence of judges in law enforcement practices violations of the code of ethics in various forms, therefore the judicial commission as a supervisory and balancing function of the judiciary (judicial power).

What exactly is meant by the concept of judicial independence? It is a concept that suggests that judges ought to be free from influence by the other branches of government, as well as from political, social, economic, or other influences. For the British, judicial independence meant that judges should be free from influence by the King or Parliament. For us in the United States, judicial independence means that judges should be free from influence by the executive or legislature. And in fact, judicial independence also means that judges should be free from influence by the people. Of course, judges are bound to follow the law, which the people may revise or amend through their representatives in the legislature. Naturally, judges should make their decisions according to the law, but otherwise should not be influenced by what the executive, the legislature, or even the people might think. Under this view, the ideal judge is a person who is learned in the law and who is independent, so that he or she will be guided in decision, making solely by legal knowledge and judicial experience (Jeffrey M. Sharman, 1996).

\section{DISCUSSION}

\section{Ethical Law Enforcement}

The Supreme Court's independence as an institution and that of its judges is undoubted and has lead to strong public confidence in the administration of justice. We recognize that the purpose of judicial independence is to serve the public, not the judges (Ian Binnie, 2011)

The emergence of a Judicial Commission that has the authority to conduct oversight of (moral norms) the behavior of judges, is a breakthrough that engenders a shift in meaning to ethical norms. Likewise, the MPR Stipulation on National Ethics (MPR Decree NO. VI / 2001), regulates that State Officials will submit to the Ethics of National Life as a formula derived from religious teachings, especially those that are universal, and the noble values of the nation's culture reflected in the Pancasila as a basic reference in thinking and behaving in national life. The awareness of the importance of moral norms has been realized by the Indonesian people, especially since the constitutional amendment by pouring a number of ethical provisions in the constitution. The 1945 Constitution of the Republic of Indonesia (hereinafter written in the 1945 Constitution) regulates moral norms in several paragraphs. The president and vice president can be dismissed for committing misconduct, as well as for judges and constitutional judges and members of the judicial commission. This means that even if there is no violation of the law of corruption for example, if they have been proven to have committed a disgraceful act then they can be dismissed from their positions. Inclusion of moral norms in a number of provisions in the 1945 Constitution indicates that law enforcement alone is not enough, it is also necessary to enforce ethical norms.

Ethical norms or also referred to as moral norms differ from legal norms (Theo Huijbers, 1990). Legal norms are usually contained in a statutory regulation and strict sanctions (J. van Kan and J.H. Beekhuis, 1977), but moral norms live in society and sanctions are not strict. In the flow of legal positivism, Hart explained that there is no need for a relationship between moral norms and legal norms, that is, moral norms stand alone beside legal norms (W. Friedmann, 1990).

If a regulative norm exists, a behaviour is no longer optional. Using a language introduced by Herbert Hart that produced a turning point in legal theory, normativity can be understood in terms of justificatory reasons for action. There are different kinds of reasons and norms, and the law is one of them. Although Kelsen did not use this language, he would accept that if something is normative it binds behaviour. The relevant point here is that Kelsen and Hart can coherently assert that normativity is one of the essential features of every legal system precisely because they clearly distinguish legal normativity 
form moral normativity. By asserting that the law is normative, they are not attributing any moral property to it. Legal normativity does not constitute nor imply moral normativity (Maria Cristina Redondo, 2019).

However, not all of the two norms must always be separated, because in other parts the two norms are sometimes difficult to separate. Fuller said that law and morals cannot be separated because the concept of law itself contains moral values (Suri Ratnapala, 2009). For example: the norm is prohibited from killing, prohibited from cheating, prohibited from stealing and is not allowed to slander. All examples of prohibition norms are also legal norms which also contain elements of moral norms. Indeed, it would be better if a moral norm is used as a legal norm through legislation or joint regulations, thus it can be subject to strict sanctions, unlike sanctions imposed on violations of moral norms. The distinction betwen law and morality was delimitated rather slowly. In the primitive stages of the social life there was an indistinct tradition, consisting in norms with a mixed character, in other words an obligatory force little defined in its moral or legal nature. (Bogdan Cristian Trandafirescu, 2007). In addition, the level of adherence to legal norms containing moral norms is expected to be better because basically the community has long known these norms in the form of moral norms that are rooted in conscience.

\section{Supervision of Judges' Behavior}

As Hart mentioned above that moral norms (ethics) need not relate to legal norms. But now it has developed the thought of the need for moral norms to be adopted as legal norms in a law. In this case, Article 24B of the 1945 Constitution jo. Law Number 22 of 2004 concerning the Judicial Commission (hereinafter referred to as Law KY) can be used as a concrete example that moral norms can be adopted into legal norms. Therefore, violation of the norm will result in strict sanctions, even if not in a criminal sentence, because the violation is a violation of the judge's code of conduct. For example, a judge who commits a despicable act, which when viewed from a legal standpoint, has not yet reached the qualifications of a criminal offense, but is still threatened with sanctions, namely sanctions for violating ethics. Therefore, the Judicial Commission has the role as the first guard in efforts to prevent violations of the law committed by the judges. A judge who negotiates with a party regarding a decision has been deemed to have violated a heavy code of ethics even though in the negotiations there has been no handover of valuables or money as bribes. So the act of his speech has not yet occurred but the act of violation of his code of ethics has occurred, and here $\mathrm{KY}$ is allowed to investigate it.

With a strict ethical supervision of judges' behavior accompanied by the threat of administrative sanctions, it will make judges think twice or thrice when they want to commit unlawful acts. Only violating ethics is already given sanctions, especially if it violates the law. If the judge's behavior is well preserved, then the people's expectation to obtain a fair court decision will be easily realized. Judges who don't violate ethical norms are good judges, and good judges make good decisions (Abdulkadir Muhammad, 2001). As an example the application of ethical norms can be seen in The Bangalore Principles (hereinafter written Bangalore Principles), which contains the basic principles of judge behavior(http://www.transparency.org/building_coalitions/codes/bangalore_conduct.html, 2020).

Ethical principles reflect the core values of the judiciary and provide a soul to the conduct of court and to individual judges. Ethics means an intention to make well, with the aim of the common good in the exercise of a task.40 It is a process; not something static. Ethical principles incarnate constitutional and lawful obligations of judges and describe the ways they must be administered. In addition, the principles set the standards of professional activity for judges and describe main features of a professional judge. Finally, they explain clearly to the society the way justice is administered, seeking the confidence for judges in individual cases and for the courts and judiciary in general. The systematic construction of ethical norms is one of the main issues that countries face while establishing documents on judicial ethics. The content of judicial ethics requires constant and continuing comparative research, because the permanent rise of new judicial ethical dilemmas leads to renewable contents. In this article, the author sets the goal to make a comprehensive list of principles of judicial ethics that enables developers of judicial ethics to test existing regulation and to improve possible reforms (Mindaugas Šimonis, 2017).

The Bangalore Principle is a code of ethics for judges' conduct that is compiled and agreed upon by representatives of judges from various countries as a guide to the behavior of judges everywhere.

The Bangalore Principles Agreement was first coined in Bangalore, India, in February 2001. The last meeting in The Hague in November 2002, which produced a draft entitled "The Bangalore Principles of Judicial Conduct" which produced six basic ethical principles of judges, namely: (1) freedom, (2) impartiality, (3) integrity, (4) politeness, (5) equality, and (6) competence and obedience. The six principles can be briefly outlined as follows: (The Bangalore Principles Of Judicial Conduct, 2002). 
1. Freedom is a prerequisite for the rule of law and a fundamental guarantee for a fair trial. Therefore a judge must uphold and give an example of judicial freedom;

2. Impartiality is very important that a judge in carrying out his duties does not expect compensation, and without prejudice. A judge must ensure that his behavior, both inside and outside the court, is maintained;

3. Integrity regulates that a judge must ensure that his behavior is not blameworthy from a reasonable observation point of view;

4. Propriety/ Politeness requires that a judge avoid inappropriate behavior and image in all judge's activities, and must be willing to accept personal restrictions that may be considered burdensome by the public;

5. Equality, ensure equal treatment of all people before the court. A judge must be aware of and understand the diversity of society arising from various sources, such as skin color, religion, beliefs, sex, and ethnicity;

6. Competence and obediences, place the judge in the position of devoting his professional activities above all other activities. A judge will take serious steps to improve his knowledge, expertise and personal qualities to carry out his duties.

The chief weakness of the Bangalore Principles lies in their enforcement. There are two facets to the enforcement problem. First, the Bangalore Principles of Judicial Conduct, like other judicial independence standards, are not contained in a binding document under international law. States are not bound to comply with their provisions in the same manner that they are with regard to international treaties. Unlike other international standards on judicial independence, it would be difficult to argue that the principles reflect customary international law. They have been developed outside traditional UN processes for generating international standards, lowering their status and creating the theoretical risk that they might be inappropriately amended by states if their adoption is sought by the international community. This fear may be unfounded as the UN Commission on Human Rights in resolution 2003/43 adopted without a vote - noted the Bangalore Principles without amendment and brought them to the attention of member states for consideration. Furthermore, at the 2006 session of the UN Economic and Social Council, member states were invited to encourage their judiciaries to consider the principles in the process of developing or reviewing professional standards of conduct. The resolution also envisages the creation of an open-ended intergovernmental expert group that would prepare a commentary on the principles in cooperation with the Judicial Group. Second, the Bangalore Principles appear to offer guidance to members of the judiciary, rather than to set out directly enforceable standards of behaviour, and therefore may not have a direct impact on improving judicial conduct. The standards contained are not expressed in a manner that enables their direct application or incorporation into domestic law as enforceable rules of conduct. Nor do they specify the standard or burden of proof, or the types and scale of penalties that can be imposed for an infraction. In terms of implementation they simply call upon national judiciaries to adopt effective measures to provide implementation mechanisms if they are currently not in existence. They do not elaborate further on what an appropriate mechanism for the enforcement of the standards contained therein should look like, apart from the fact that it should be generated from within the judiciary, although other international standards on judicial independence may provide some guidance in that respect (Greg Mayne, 2007).

Despite these weaknesses, a key strength of the Bangalore Principles is their recognition that judiciaries are not passive players in terms of maintaining the independence, impartiality and effectiveness of a judicial system, and therefore its integrity, but must be active in maintaining appropriate standards of judicial conduct and performance. Other instruments elaborated by the international community have tended to dismiss the need for standards of conduct for the judiciary and the role of the judiciary in this regard, and emphasise the responsibilities of the state. The promulgation of the principles outside the traditional UN or inter-governmental processes indicates a growing awareness among judges that efforts to strengthen judicial independence need also to strengthen judicial accountability and that judges themselves must play an active role in upholding high standards of conduct in order to contribute to the strengthening and institutionalisation of judicial independence. (Greg Mayne, 2007).

The legal rules related to the task of supervising judges' behavior are scattered in various laws and regulations. They are the 1945 Constitution Article 24B, Judicial Commission Law (Law KY) No. 18 of 2011 as Amendments to Law 22 of 2004, Law Number 3 of 2009 concerning Second Amendment to Law Number 14 of 1985 regarding the Supreme Court (Law MA), Law No. 49, 50 \& 51 of 2009 concerning General Courts (Law PU), Religious Courts (Law PA), and State Administrative Courts (Law PTUN).

Along with the issuance of the Supreme Court Act 2009 above the Judicial Commission together with the Supreme Court on April 8, 2009 has ratified the Joint Decree (SKB) on the Code of Ethics and the 
Code of Conduct for Judges (KE \& PPH) which regulates the ethics and behavior of prohibited judges. KE (Code of Ethics) \& PPH (Judges' Code of Conduct) are also one of the ethical norms that have been positively promoted thus they have strict sanctions that apply to judges. The contents of the Code of Ethics (KE) \& PPH basically contain about 10 principles, namely (1) Behaving Fairly, (2) Being Honest, (3) Behaving Arif and Wise, (4) Being Independent, (5) High Integrity, (5) 6) Responsible, (7) Uphold SelfEsteem, (8) High Discipline, (9) Be Humble, and (10) Be Professional.

KE \& PPH regulation above is in line with the provisions in Article 11A paragraph (1) letter F of the Supreme Court Law which in essence states that the Supreme Judge can be dishonorably discharged if it violates the KE \& PPH. The above provisions are concrete forms of the application of strict sanctions against violations of ethical norms. Then Article 11A paragraph (6) of the Supreme Court Law states that the Supreme Judge who violates KE \& PPH has the right to defend himself before the Honorary Board of Judges (MKH) before the Supreme Court and / or Judicial Commission proposes the dismissal of sanctions. With the affirmation of the article, the Judicial Commission together with the Supreme Court can hold MKH. MA Supreme Court regulation above has become a reference for the drafting of PU Law, PA Law and PTUN Law, thus judges under the Supreme Court also have the same defense rights before MKH.

\section{Imposition of Sanctions Mechanism}

Judges found guilty of violating KE and PPH were severely sanctioned with dishonorable discharge by the Judicial Commission Ethics Session. Before the sanctions have binding force, the judge in question must be given the opportunity to defend himself before the MKH hearing). Then MKH delivered the sanction to the Supreme Court to be implemented. So far (before 2013) the heavy sanctions imposed by KY on judges were violations of the KE and PPH related to criminal acts such as being a case broker, accepting bribes, and getting part of the object of the case. Actually this matter has entered into the realm of criminal law, so the sanction of dismissal should be accompanied by a report of criminal actions to law enforcement according to the type of case..

Behavior related to criminal act is no longer an ethical issue, because ethical issues are only related to matters that are proper or inappropriate, bad or good, the legal sanctions are certainly different from the penalties. KY was not present to punish criminal offenders but rather as guardians and enforcers of honor, dignity and behavior of judges both inside and outside the trial. The judge's behavior in the trial can manifest in the manner of presiding over the hearing and other behaviors in the hearing, such as partiality in leading the trial, lying in formulating his legal opinion, or deliberately ignored evidence or facts of the trial. Such judge behavior is clearly bad or inappropriate behavior. Examples of out-of-court behavior include gambling, drunkenness, meeting with litigants, and doing despicable or immoral behavior.

Behavior of such judges has committed acts that demean the honor, dignity, and behavior of themselves, to the judge who proved to be reasonable if imposed sanctions. This sanction is not merely a punishment but also a rescue of judicial institutions and the maintenance and upholding of the honor of the noble conduct of judges. Conversely, if the honor, dignity and behavior of judges are dropped by another party, then according to the Judicial Commission Law No. 18 of 2011 Article 20 paragraph (1) c, KY may take legal or other steps against those who demean the judge's dignity.

The mechanism for imposing sanctions is a problem if the sanctions given by KY against judges are medium category sanctions, such as temporary termination by delaying promotion or non-hammer for a certain time. Some of these sanctions up to now have not been implemented or executed by the Supreme Court.

For judges who are proposed with severe sanctions such as dismissal, will be given the opportunity to conduct self-defense in the MKH session. It could be after making a defense at MKH, the sanction may turn into a mild sanction in the form of a warning, or it may even be released because according to MKH there is not enough evidence. For light sanctions it is still open for judges to participate in the selection of prospective justices. Therefore judges who have been sentenced to dismissal either by KY or by the Supreme Court but have never been given the opportunity to conduct self-defense at the MKH session are a great loss for the judge himself.

After the New KY Act came into effect, namely Law Number 18 of 2011, the sanctions imposed by the KY Plenary Session on the Reported Judge, in addition to dismissal, automatically took place after 60 days the Supreme Court did not show an attitude of disapproval. If the Supreme Court feels objected to the sanctions proposed by the Judicial Commission, then a joint examination by the Judicial Commission and the Supreme Court. In the case of a joint examination no agreement was found, then KY proposals apply automatically and must be implemented by the Supreme Court (see Articles 22D and 22E).

For dismissal sanctions, the Judicial Commission proposed to the Supreme Court to be formed by the MKH with members of the panel consisting of $4 \mathrm{KY}$ members and 3 members of the Supreme Court 
Judge. MKH checks and decides the alleged violation of the Code of Ethics and / or the Code of Conduct of Judges proposed by KY or MA within 60 days from the receipt of the proposal. MKH decisions must be implemented by the Supreme Court within a 30-day deadline from the date the decision was made (Article 22F).

\section{Judicial Commission as Ethics Court}

Under the Constitution of the Judicial Commission then formed by calling two constitutional authorities. They were to select prospective judges and to have other powers in order to maintain and uphold the honor, dignity, and behavior of judges.

The other authority of the Judicial Commission to maintain and uphold the honor, dignity and behavior of judges must be interpreted that the honor, dignity and behavior of judges must not be kept from falling down either due to their own actions or due to the actions of other parties. The judge's decision is the judge's dignity and honor, so if the judge plays his decision, in fact he has dropped his own dignity and honor. Likewise, if the judge's behavior is inappropriate or not in accordance with the moral code, both inside and outside his official duties, in fact he has dropped his own honor and dignity as a judge. This is where the Judicial Commission is present to enforce it.

Constitutionally it is clearly stated that the guardian and enforcer of a judge's behavior is the task of the Judicial Commission, not another institution. Then it is a constitutional error if there are other institutions given the authority to guard or handle the behavior of judges. However, the 2009 Judicial Act and the 2009 Supreme Court Act stated that internal control over judges' behavior is carried out by the Supreme Court. The formulation of the Supreme Court as the supervisor of the judge's behavior creates confusion if juxtaposed with the authority of the Judicial Commission as the guardian and enforcer of the judges' behavior as mandated in Article 24B of the 1945 Constitution. Likewise it is a constitutional error if the Judicial Commission by law is given the task of supervising or evaluating Judges' verdicts, because the matter of judges' decisions is a judicial affair which is the duty and authority of the Supreme Court as regulated in Article 24 of the 1945 Constitution. The definition of attitude and behavior clearly has the same meaning, namely the action including the attitude of the judge. Thus the formulation of the task of supervising the behavior or behavior of judges by institutions other than the Judicial Commission is actually an unconstitutional formula, not in accordance with Article 24B of the 1945 Constitution. In addition to being unconstitutional, it also complicates and results in a waste of the State budget because in practice between the Judicial Commission and the Supreme Court conducted by the Supervisory Agency (Bawas) is often in conflict because the object of supervision is the same judge. The Reported Judge examined by the Judicial Commission is often re-examined by the Supreme Court Supervisory Board in the same case and also vice versa, of course this is detrimental to the judge as the Reported Party.

The presence of the Judicial Commission as a supervisor of the actual behavior of judges is also expected by the Supreme Court as can be seen in the initial idea of the formation of the MPPH (Judicial Research Advisory Panel) in 1968. MPPH is expected to assume the function of giving recommendations for appointment, promotion, dismissal and acts of punishment (Secretariat General of the Judicial Commission, t.th).

With this position, the function of the Judicial Commission is basically closely related to the function of the judicial authority (judicial) as is the case with court institutions. If the court of law institution has the function to adjudicate legal cases, the Judicial Commission also has the function as a court of ethics which hears the ethical cases (behavior) of the judges (Jimly Asshiddiqie, 2013), therefore it is time for the general principles of modern courts to apply also to the ethical courts in the Judicial Commission. MKH (Honorary Panel of Judges) which is conducted openly has shown that the ethical court hearing has fulfilled the principles of the court of law. Thus the Chapter of Judicial Power listed in the 1945 Constitution must now be read not only by judicial authority in the field of law carried out by the Supreme Court along with the court under it and a Constitutional Court, but also includes judicial power in the field of ethics carried out by the Judicial Commission. So the placement of the Judicial Commission in the Chapter of Justice was correct.

As a comparative law, before 1985 Indonesian people only knew the General Courts, Religious Courts, and Military Courts, but after 1985 the community recognized the State Administrative Court institutions whose object of dispute was a decree from an administrative official, which of course at the beginning of its appearance by the public was seen "Strange" is not uncommon. Then at the beginning of the reforms after the amendment to the 1945 Constitution of 2003 the community was introduced to the State Constitutional Court institution conducted by the Constitutional Court with the authority to, among other things, adjudicate laws and dispute the authority of state institutions, as well as the birth of the Ethics Court conducted by the Judicial Commission with the object of non-legal cases namely the ethical 
norms that are arranged in the Code of Ethics and the Code of Conduct for Judges. So now the community has been introduced to six models of court institutions namely the General Courts, Religious Courts, Military Courts, Administrative Courts, Administrative Courts and Ethical Courts. In the general election organizer known as the Ethics Court conducted by the Election Management Honorary Board (DKPP).

\section{Experience of the Honorary Panel of Judges}

The experience of the Judicial Commission and the Supreme Court organizing the Honorary Panel of Judges often issued Law Number 3 of 2009 concerning the Second Amendment to Law Number 14 of 1985 concerning the Supreme Court. Article 11A paragraph (6) provides that before the Supreme Court and / or the Judicial Commission submit proposals for dismissal from both the Supreme Court and the Judicial Commission, the Supreme Court justices have the right to defend themselves before the Honorary Panel of Judges. A similar mechanism was used by judges in all Supreme Court circles as Law Number 49 of 2009 concerning Second Amendment to Law Number 2 of 1986 concerning General Courts was passed. Is Judge Sudarto who is the Chair of the Banjarmasin District Court. The decision of the Honorary Panel of Judges for the first time on September 29, 2009 dismissed the judge disrespectfully because Judge Sudarto requested a sum of money and facilities from the litigants..

Since the hearing of the Honorary Panel of Judges was held for the first time, 19 decisions of the Honorary Board of Judges have been passed. Decisions of the Honorary Panel of Judges with respect to dismissal from the position of judge / justices as many as 7 (seven) decisions, the rest in the form of sanctions with respect to dismissal not on their own request, and sanction of judicial judges for a certain time. Of the 19 decisions of the Honorary Panel of Judges, 10 (ten) of which are proposed by the Judicial Commission, the rest are proposals from the Supreme Court. Decision of the Honorary Panel of Judges is a decision related to the dismissal of the Honorable Chief Justice Ahmad Yamani. As the only supreme court judge who was dishonorably dismissed, Ahmad Yamani was fired for changing the decision on the conviction of convicted Hanky Gunawan from a 15-year prison sentence to 12 years as a judicial review panel had decided. This was done by inserting three new lines of consideration in the previously agreed draft decision, namely a 15-year prison sentence.

The experience of holding an Honorary Panel of Judges was also colored by dissenting opinions. Judges' Honorary Council Decisions Number 02 / MKH / XI / 2009 and 03 / MKH / XI / 2009 also have disenting opinions. The request for a sum of money made by the reported judge to the reported party is the reason for the submission of Judge Ari Siswanto and Judge Aldhytia Kurniyansa Sudewa to the Honorary Panel of Judges. Certainly both are recommended by the Judicial Commission to be dismissed from the post of judge. In its decision on December 14, 2009, the Honorary Panel of Judges imposed sanctions as a judicial judge, demotion 1 (one) lower with the legal consequences reduced remuneration allowance of $100 \%$ while serving as a judicial judge.

Legal considerations in 2 (two) decisions of the Honorary Panel of Judges contain disenting opinions. In the decision of the Honorary Panel of Judges with reported judge Ari Siswanto, Artidjo Alkostar (chief judge of the Honorary Panel of Judges from the Supreme Court elements) and Zainal Arifin (judge members of the Honorary Board of Judges of the Supreme Court elements) who expressed differences of opinion that the reported judge was dismissed with no respect as a judge. Whereas the decision of the Honorary Panel of Judges and reported judge Aldhytia Kurniyansa Sudewo, Zainal Arifin is consistent with the recommendation of the Judicial Commission to dismiss the reported judge with respect.

The establishment of a Judge Honorary Council which is a forum of self-defense by judges in the mechanism for dismissing judges is relevant to the urgency of establishing a Judicial Commission as referred to above. The study of legal politics further explores the main idea of establishing an Honorary Panel of Judges as part of the supervisory mechanism of judges, especially in dismissing judges. Political study of law related to the Honorary Council of Judges will confirm the existence of legal policy from the legislators in balancing the position of the Supreme Court and the Judicial Commission in the mechanism of dismissing judges. The establishment of the Honorary Council of Judges further emphasized the country's commitment to make improvements to the independence of an accountable judicial power.

From the experience of forming the Honorary Panel of Judges above, 24 Honorary Board Judges have been held. Establishment of Honorary Panel of Judges with these figures, 12 proposals from the Supreme Court and 12 from the Judicial Commission. A total of 13 judges have been dismissed through the Honorary Panel of Judges. The formation of the Honorary Panel of Judges in accordance with the legal politics of its formation, among others:

a. The Honorary Panel of Judges is able to act against judges who violate the Code of Ethics and the Code of Conduct for Judges. This can be seen from the experience of the formation of the Honorary Panel of Judges capable of acting against judges who violated the Code of Ethics and the Code of 
Conduct for Judges because of several violations such as receiving gifts from litigants, communicating with litigants, and immoral acts;

b. The establishment of a Judge Honorary Council is a concrete step in supervising judges. Both external oversight by the Judicial Commission and internal oversight by the Supreme Court, the Honorary Panel of Judges are repressive measures in taking action against judges who violate the Code of Ethics and the Code of Conduct of Judges in the framework of supervising judges;

c. The establishment of the Honorary Panel of Judges has carried out repressive judicial oversight functions as a defense forum for judges who violate the Code of Ethics and the Code of Conduct for Judges, independently and not influenced by executive or legislative powers in imposing sanctions on judges;

d. The establishment of the Honorary Panel of Judges is a form of balance of authority between the Supreme Court as an internal supervisor and the Judicial Commission as an external supervisor, in following up on the proposed dismissal of the judge. Therefore, there is no dominant institution in both the Supreme Court and the Judicial Commission in proposing the dismissal of judges as well as deciding;

e. The formation of the Honorary Panel of Judges supports the implementation of the independence of the judicial authority and accountability of the judicial authority. The establishment of a Judge Honorary Council is part of a repressive effort to crack down on judges who violate the Code of Ethics and the Code of Conduct for Judges. Actions against judges who violate the Code of Ethics and the Code of Conduct for Judges through the Honorary Council of Judges are relevant to the spirit of building a judge's mentality thus they are independent in examining, adjudicating, and deciding cases. In addition, the exercise of judicial power is accountable in accordance with the principles contained in the Code of Ethics and the Code of Conduct for Judges.

\section{CONCLUSION}

Based on the discussion above, the conclusion of this article can be given, that the judge as the judge of justice must be guaranteed independence, he must not be influenced by anyone. An independent judge will provide equal and open opportunity for each party to be heard without relating it to the identity or social position of the parties. An independent judge will be impartial, free from unrelated influence and immune from outside pressure. An independent judge decides on the basis of honesty, based on the law as he knows it, regardless of personal, political or financial consequences. Judges are considered as representatives of God above the world, and whatever decision is true (res judicata pre veritate habetur) regardless of whether when deciding a judge is influenced by wrong behavior or contrary to law and ethics.

The Judicial Commission of the Republic of Indonesia (KY RI) has the role as the first guard in efforts to prevent ethical and legal violations committed by judges. A judge negotiating with a litigant regarding a decision has been deemed to have violated a severe code of ethics even though the negotiations did not yet take place of valuables or money as bribes. The criminal act has not yet occurred, but the violation of the code of ethics has already occurred, and here KY can investigate it, thus the Judicial Commission only conducts investigations until the conviction for ethical violations has been given a sanction, especially if it violates the law. If the judge's behavior is well preserved, then the people's expectation to obtain a fair court decision will be easily realized.

The existence and function of the Judicial Commission is very much related to the function of the judicial authority (judicial) as is the case with court institutions. If the court of law has the function of adjudicating legal cases, the Judicial Commission also has the function of an ethical court which adjudicates the ethical cases (behavior) of the judges, so it is time that the general principles of the modern court apply for an ethical court in the Judicial Commission. MKH (Honorary Panel of Judges) which is conducted openly has shown that the ethical court hearing has fulfilled the principles of the court of law.

\section{REFERENCES}

Asshiddiqie, Jimly. (2013). Upholding Election Organizer Ethics, Jakarta: Rajagrafindo Persada.

Binnie, Ian. (2011). Justice on behalf of the Supreme Court of Canada, Judicial Independence in Canada, p. 2.

Blueprint for Updating the Judicial Commission 2010-2025. (2010). Jakarta: The Judicial Commission of the Republic of Indonesia.

Friedmann, W. (1990). Legal Theory \& Philosophy, cet.I, Jakarta: Rajawali Pers. 
http://www.transparency.org/building_coalitions/codes/bangalore_conduct.html, accessed April 15, 2020.

Huijbers, Theo. (1990). Philosophy of Law, Jakarta: Kanisius.

Kan, J. van \& Beekhuis, J.H., (1977). Introduction to Law, Jakarta: Ghalia Indonesia.

Joint Decree of the Chairperson of the Supreme Court of the Republic of Indonesia and the Chair of the Indonesian Judicial Commission Number 047 / KMA / SKB / IV / 2009 and 02 / SKB / P.KY / IV / 2009 concerning the Code of Ethics and the Code of Conduct of Judges.

MPR Decree NO. VI / 2001 concerning Ethics of National Life.

Lowndes, John. (2016). Judicial Independence and Judicial Accountability at the Coalface of the Australian Judiciary, Presented by Chief Judge of the Local Court of the Northern Territory of Australia at the Northern Territory Bar Association Conference in Dili East Timor, p.1.

Mayne, Greg. (2007). Judicial Integrity: The Accountability Gap and The Bangalore Principles, Accountability and Competence of Judges, Global Corruption Report, p. 43.

Muhammad, Abdulkadir. (2001). Legal Professional Ethics, Bandung: Aditya Bakti.

Ratnapala, Suri. (2009). Jurisprudence, Australia: Cambridge University Press.

Redondo, María Cristina. (2019). Legal normativity as a moral property. Revus Journal for Constitutional Theory and Philosophy of Law/Revija za ustavno teorijo in filozofijo prava, 37, p.60, DOI: 10.4000/revus.4825, http://journals.openedition.org/revus/4825.

Secretariat General of the Judicial Commission, Minutes of the RI Judicial Commission, Jakarta, without year.

Sharman, Jeffrey M. (1996). Judicial Ethics: Independence, Impartiality, and Integrity, Inter-American Development Bank Washington, D.C. Sustainable Development Department State, Governance and Civil Society Division Judicial Reform Roundtable II, p.3.

Šmonis, Mindaugas. (2017). The Role of Judicial Ethics in Court Administration: From Setting the Objectives to Practical Implementation, Baltic Journal of Law \& Politics A Journal of Vytautas Magnus University VOLUME 10, NUMBER 1 (2017) ISSN 2029-0454, p.110-111. DOI: 10.1515/bjlp-2017-0004, http://www.degruyter.com/view/j/bjlp

The Bangalore Principles of Judicial Conduct. (2002). Adopted by the Judicial Group on Strengthening Judicial Integrity, as revised at the Round Table Meeting of Chief Justices held at the Peace Palace, The Hague, November 25-26, p.1-11.

Tohari, A. Ahsin. (2004). Judicial Commission and Judicial Reform, Jakarta: ELSAM.

Trandafirescu, Bogdan Cristian. (2007). The Juridical Norm and the Moral Norm, (The $6^{\text {th }}$ International Conference of PhD students, University of Miskolc, Hungary, 12-18 august, Published by University of Miskolc, Inovation and Thechnology transfer centre, ISBN 978-963-661-783-7 Ö, p.2, ISBN 978963-661-782-0) DOI: 10.13140/2.1.2615.4883.

Lowndes, John. (2016). JUDICIAL INDEPENDENCE AND JUDICIAL ACCOUNTABILITY AT THE COALFACE OF THE AUSTRALIAN JUDICIARY, Presented by Chief Judge of the Local Court of the Northern Territory of Australia at the Northern Territory Bar Association Conference in Dili East Timor, p.1.

Sharman, Jeffrey M. (1996). Judicial Ethics: Independence, Impartiality, and Integrity, Inter-American Development Bank Washington, D.C. Sustainable Development Department State, Governance and Civil Society Division Judicial Reform Roundtable II, p.3.

Binnie, Ian. (2011). Justice on behalf of the Supreme Court of Canada, JUDICIAL INDEPENDENCE IN CANADA, p. 2.

Trandafirescu, Bogdan Cristian. (2007). THE JURIDICAL NORM AND THE MORAL NORM, (The $6^{\text {th }}$ International Conference of PhD students, University of Miskolc, Hungary, 12-18 august, Published by University of Miskolc, Inovation and Thechnology transfer centre, ISBN 978-963-661-783-7 Ö, p.2, ISBN 978-963-661-782-0) DOI: 10.13140/2.1.2615.4883.

Redondo, María Cristina. (2019). Legal normativity as a moral property. Revus Journal for Constitutional Theory and Philosophy of Law/Revija za ustavno teorijo in filozofijo prava, 37, p.60, DOI: 10.4000/revus.4825, http://journals.openedition.org/revus/4825

THE BANGALORE PRINCIPLES OF JUDICIAL CONDUCT. (2002). Adopted by the Judicial Group on Strengthening Judicial Integrity, as revised at the Round Table Meeting of Chief Justices held at the Peace Palace, The Hague, November 25-26, p.1-11.

Šimonis, Mindaugas. (2017). The Role of Judicial Ethics in Court Administration: From Setting the Objectives to Practical Implementation, BALTIC JOURNAL OF LAW \& POLITICS A Journal of Vytautas Magnus University VOLUME 10, NUMBER 1 (2017) ISSN 2029-0454, p.110-111. DOI: 10.1515/bjlp-2017-0004, http://www.degruyter.com/view/j/bjlp 
Mayne, Greg. (2007). Judicial Integrity: The Accountability Gap and The Bangalore Principles, Accountability and Competence of Judges, Global Corruption Report, p. 43.

1945 Constitution of the Republic of Indonesia.

Law of the Republic of Indonesia Number 3 of 2009 concerning Second Amendment to Law Number 14 of 1985 concerning the Supreme Court. 